\title{
ACE- inhibitory and radical scavenging activities of bioactive peptides obtained from camel milk casein hydrolysis with proteinase $\mathrm{K}$
}

\author{
Mahmood Rahimi ${ }^{1}$ - Seyed Mahmood Ghaffari ${ }^{1} \cdot$ Maryam Salami $^{2}$ • \\ Seyed Jafar Mousavy ${ }^{3}$ - Amir Niasari-Naslaji ${ }^{4}$ - Raheleh Jahanbani ${ }^{1}$ • \\ Saeed Yousefinejad ${ }^{1}$ - Mohammadreza Khalesi ${ }^{1,5}$. \\ Ali Akbar Moosavi-Movahedi ${ }^{1,6}$
}

Received: 26 August 2015 / Revised: 23 February 2016 / Accepted: 26 February 2016 /

Published online: 2 May 2016

C) INRA and Springer-Verlag France 2016

\begin{abstract}
The aim of this study was to evaluate the effects of enzymatic hydrolysis of camel whole casein on their antioxidant and angiotensin-converting enzyme (ACE)inhibitory properties. Whole camel casein was hydrolyzed by proteinase $\mathrm{K}(\mathrm{PK})$, and the hydrolysates were fractionized by ultrafiltration membranes into three fractions. Semi-preparative reversed-phase high-performance liquid chromatography (RP-HPLC) was used to differentiate the mixture of peptides in the $3 \mathrm{kDa}$ permeate fractions. A fraction (F4) with potentials of ACE-inhibitory activity $\left(\mathrm{IC} 50=73 \mu \mathrm{g} \cdot \mathrm{mL}^{-1}\right.$ ) and radical scavenging activity $\left(\mathrm{IC} 50=6.8 \mu \mathrm{g} \cdot \mathrm{mL}^{-1}\right.$ ) was selected for further purification and fractionation. The fraction $\mathrm{F} 4 \mathrm{C}$ obtained from a second step purification of $\mathrm{F} 4$ showed strong ACE-inhibitory activity $\left(\mathrm{IC}_{50}=36 \mu \mathrm{g} \cdot \mathrm{mL}^{-1}\right)$ as well as radical scavenging activity $\left(\mathrm{IC}_{50}=3.3 \mu \mathrm{g} \cdot \mathrm{mL}^{-1}\right)$. The results of this study suggest that whole camel casein can be considered as a promising source for the production of peptides with potential of ACE-inhibitory and antioxidant activities.
\end{abstract}

Ali Akbar Moosavi-Movahedi

moosavi@ut.ac.ir

1 Institute of Biochemistry and Biophysics, University of Tehran, Tehran, Iran

2 Department of Food Science and Engineering, University College of Agriculture and Natural Resources, University of Tehran, Karaj, Iran

3 Department of Biology, Faculty of Basic Sciences, Imam Hussein University (IHU), Tehran, Iran

4 Department of Clinical Sciences, Faculty of Veterinary Medicine, University of Tehran, Tehran, Iran

5 Department of Food Science and Technology, Shiraz University, Shiraz, Iran

6 Center of Excellence in Biothermodynamics, University of Tehran, Tehran, Iran 
Keywords Camel milk $\cdot$ Casein $\cdot$ Peptide $\cdot$ Protease $\cdot$ Angiotensin-converting enzyme

\section{Introduction}

Milk proteins and milk protein-derived peptides have important roles as human nutrition and promotion of health (Korhonen and Pihlanto 2007). These proteins are among the main sources of bioactive peptides, which are generally latent within the sequence of food proteins (Clare and Swaisgood 2000). When these peptides are released, either during the food processing (by enzymatic hydrolysis or fermentation) or during the gastrointestinal digestion from parent proteins, they may exhibit important biological functions such as antioxidant, antimicrobial (Salami et al. 2010), antihypertensive (Quan et al. 2008), opioid (Shabo and Yagil 2005), mineral binding (Gorban and Izzeldin 1997), hypocholesterolemic (Ali et al. 2013), immunemodulatory (Takeda et al. 2011), and anti-proliferative activities (Habib et al. 2013).

It has been elucidated that many peptide sequences in milk proteins have angiotensin-converting enzyme (ACE)-inhibitory activity (Jrad et al. 2014; Otte et al. 2007). The angiotensin I-converting enzyme (ACE, EC 3.4.15.1) is a dipeptidyl carboxypeptidase which regulates the blood pressure (Hooper 1991). ACE may inactivate the bradykinin (a potent vasodilator) by removing its carboxyl terminal phenylalanyl-arginine dipeptide. On the other hand, by removing histidylleucine dipeptide from angiotensin I (an inactive decapeptide), ACE catalyzes the formation of angiotensin II (a potent vasoconstriction octapeptide) (Skeggs et al. 1957). Thus, inhibition of this dipeptidyl carboxypeptidase can significantly drop the blood pressure.

Although the bioactivity of the milk-derived peptides from different sources has been extensively studied, only few attempts have been made to investigate the peptides from camel milk proteins (Jrad et al. 2014; Moslehishad et al. 2013; Salami et al. 2011). Jrad et al. (2014) hydrolyzed the camel milk protein by pepsin and pancreatin and evaluated the antioxidant and ACE-inhibitory activities of resulting peptides. Moslehishad et al. (2013), in their study, compared ACE-inhibitory and antioxidant activities of peptide fractions obtained from fermented bovine and camel milk. Salami et al. (2011) studied the effects of digestive enzymes on releasing the ACE-inhibitory and antioxidant peptides from camel milk caseins. Nevertheless, there is no available data concerning the biological functions of camel casein-derived peptides produced by a microbial enzyme, e.g., proteinase K (PK). Due to the presence of many hydrophobic amino acid residues in the camel caseins, which are potential cleavage sites for PK, this microbial enzyme has been considered a potential enzyme for hydrolysis of camel caseins. This study was conducted to investigate the ACE-inhibitory and radical scavenging potential of the peptides from enzymatic hydrolysis of camel milk caseins.

\section{Materials and methods}

\subsection{Materials}

Fresh camel (Camelus dromedarius) milk was collected from 10 local camel farms, and the samples were transported to the laboratory under sterile conditions. PK from 
Tritirachium album, bovine serum albumin (BSA), 6-hydroxy-2,5,7-8tetramethylchromane-2-carboxylic acid (Trolox), butylated hydroxyanisole (BHA), vitamin C (ascorbic acid), 2,2-azinobis(3-ethylbenzothiazoline-6-sulfonic acid) (ABTS), lung acetone powder from rabbit as a source of ACE and ophtaldehyde (OPA) were purchased from Sigma Aldrich (GmbH, Munich, Germany).

\subsection{Preparation of protein and protein hydrolysates}

Camel whole casein was prepared according to the method described earlier (Salami et al. 2011). Briefly, camel milk was skimmed by centrifugation $\left(5000 \times \mathrm{g}, 15 \mathrm{~min}\right.$ at $\left.4{ }^{\circ} \mathrm{C}\right)$. The $\mathrm{pH}$ value was then adjusted to 4.6. Keeping the solution at $37^{\circ} \mathrm{C}$ for $30 \mathrm{~min}$, the caseins were precipitated. The precipitates were separated from the transparent supernatant containing whey proteins by using centrifugation $\left(5860 \times \mathrm{g}, 60 \mathrm{~min}\right.$ at $\left.4{ }^{\circ} \mathrm{C}\right)$. The latter procedure was repeated three times. Then, the obtained caseins were lyophilized using an Alpha1-2 Lo plus, Christ, Germany, lyophilizer and stored at $-20^{\circ} \mathrm{C}$ for further analysis.

To produce bioactive peptides, enzymatic hydrolysis was conducted using PK. Camel casein $(1250 \mathrm{mg}$ ) was dissolved in $50 \mathrm{~mL}$ of $20 \mathrm{mM}$ phosphate buffer (25 mg. $\mathrm{mL}^{-1}$ ). The hydrolysis was initiated by adding $\mathrm{PK}$ at $\mathrm{pH} 6.8, T=37^{\circ} \mathrm{C}$, and the ratio of enzyme to substrate was 1:250 (w/w). After each hydrolysis reaction, the mixture was heated $\left(85^{\circ} \mathrm{C}\right.$ for $\left.15 \mathrm{~min}\right)$ to inactivate the protease. The precipitates were then removed by centrifugation of protein hydrolysates $\left(10,000 \times \mathrm{g}, 10 \mathrm{~min}\right.$ at $\left.4{ }^{\circ} \mathrm{C}\right)$, and the supernatant were collected. The latter contained the peptides. The peptides were then fractionized by ultrafiltration (UF) membranes (Amicon Ultra-15, Millipore, cutoff of 10, 5, and $3 \mathrm{kDa}$, Carrigtwahill, Co. Cork, Ireland) into three fractions. The details of fractions are given in the following sections.

\subsubsection{Degree of hydrolysis}

Degree of hydrolysis (DH) was determined using OPA solution (Church et al. 1983). For preparing the OPA solution, $40 \mathrm{mg}$ OPA was dissolved in $1 \mathrm{~mL}$ methanol; this was added to $25 \mathrm{~mL}$ of $100 \mathrm{mM}$ tetraborate. After adding $2.5 \mathrm{~mL}$ SDS $20 \%(w / w)$ and $100 \mu \mathrm{L} \beta$-mercaptoethanol, the resulting solution was diluted into $50 \mathrm{~mL}$ using deionized water. Fifty microliters of the samples were then added to $950 \mu \mathrm{L}$ of OPA reagent and after 2-min incubation, the absorbance of OPA was measured by UV-Vis spectrophotometer (Shimadzu, Model UV-3100, Kyoto, Japan) $(\lambda=340 \mathrm{~nm})$.

$\mathrm{DH}$ was calculated by the following equation:

$$
\mathrm{DH}(\%)=(n / N) \times 100
$$

where $N$ is total number of peptide bounds in the substrate, and $n$ is the number of peptide bounds hydrolyzed in a given time.

\subsubsection{Purification of ACE-inhibitory and radical scavenging activity peptides}

After fractionation of the peptides by UF membranes, semi-preparative reversed-phase highperformance liquid chromatography (RP-HPLC) (CECIL 1100 series HPLC, UK) on an ODS C18 column (10 UM, $L=250 \mathrm{~mm}, \mathrm{ID}=10 \mathrm{~mm}$ ) equipped with a $\mathrm{UV}$ detector was 
used to further fractionize the mixture of the peptides with molecular weight (MW) lower than $3 \mathrm{kDa}$ present in a fraction which exhibited significant ACE-inhibitory and radical scavenging properties. Gradient elution was conducted by a mixture of buffer A, 10\% acetonitrile containing $0.1 \%$ trifluoroacetic acid (TFA), and buffer B, $80 \%$ acetonitrile containing $0.1 \% \mathrm{TFA}$, at a flow rate of $1.5 \mathrm{~mL} \cdot \mathrm{min}^{-1}$. The absorbance was monitored at $\lambda=215 \mathrm{~nm}$. Different fractions were collected according to the profile given in Fig. 1 and then lyophilized. Then, they became lyophilized and their activities were measured. For further purification, the most active fraction was subjected again to the column (mobile phase flow rate $=1 \mathrm{~mL} \cdot \mathrm{min}^{-1}$ ). Peptide purity was evaluated by the chromatograms from RPHPLC analysis of sample on an ODS C18 $(L=250 \mathrm{~mm}$, ID =4.6 mm) column at a flow rate of $1 \mathrm{~mL} \cdot \mathrm{min}^{-1}$ and under identical elution conditions.

\subsection{ACE-inhibitory activity assay}

The ACE-inhibitory activity of the samples was measured using the method described previously (Shalaby et al. 2006; Vermeirssen et al. 2002). Three grams rabbit lung acetone extract was dissolved in $3 \mathrm{~mL}, 50 \mathrm{mM}$ Tris-HCl buffer $(\mathrm{pH} 8.3$ ) containing 5\% (v/v) glycerol, and the mixture was stirred over night at $4{ }^{\circ} \mathrm{C}$. By ultra-centrifugation of the mixture for $40 \mathrm{~min}$ at $40,000 \mathrm{~g}$, a supernatant with high ACE activity was obtained. For ACE-inhibitory activity measurement, $5 \mu \mathrm{L}$ of ACE extract and $20 \mu \mathrm{L}$ of peptide solution or deionized water were added to each of ELISA wells. In addition, $110 \mu \mathrm{L}$ of FAPGG $(1.2 \mathrm{mM})$ dissolved in $50 \mathrm{mM}$ Tris-

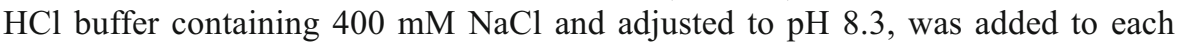
well. The decrease in the absorbance at $340 \mathrm{~nm}$ was measured using spectrophotometer equipped with an ELISA reader (for $20 \mathrm{~min}$ at $37^{\circ} \mathrm{C}$ ). The decreases in the absorbance values $\left(\triangle \mathrm{A} 340 \mathrm{~nm} \cdot \mathrm{min}^{-1}\right)$ were recorded. The ACE-inhibitory activity of each peptide samples was tested after adjusting the $\mathrm{pH}$ values to 8.0. ACEinhibitory activity was calculated according to Eq. 1:

$$
\text { ACE inhibition }(\%)=[1-(\delta A \text { inhibitor } / \delta A \text { control })] \times 100
$$

where $\delta A$ inhibitor and $\delta A$ control represent the slopes of the decrease in absorbance at $340 \mathrm{~nm}$ in the test and control samples, respectively. The ACE-inhibitory

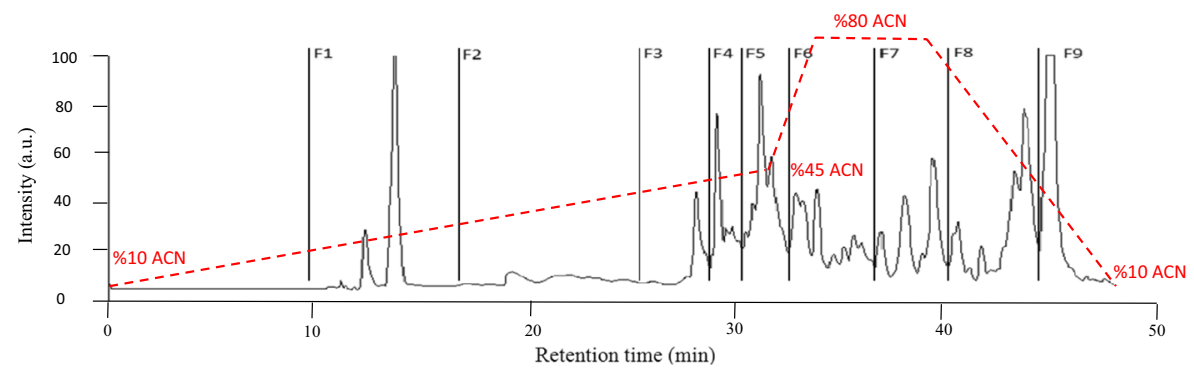

Fig. 1 A representative RP-HPLC chromatogram during fractionation of $3 \mathrm{kDa}$ permeate fraction obtained from cleavage of camel milk casein by proteinase K. For elution of the fractions from ODS C18 column (10 UM, $L=250 \mathrm{~mm}, \mathrm{ID}=10 \mathrm{~mm})$, buffer A ( $10 \%$ ACN containing $0.1 \% \mathrm{TFA})$ and buffer B $(80 \% \mathrm{ACN}$ containing $0.1 \%$ TFA) were used at a flow rate of $1.5 \mathrm{~mL} \cdot \mathrm{min}^{-1}$. The eluted fractions were monitored by UV detector at $215 \mathrm{~nm}$ wavelength 
potencies of the samples were expressed as the concentration of peptides $\left(\mu \mathrm{g} \cdot \mathrm{mL}^{-1}\right)$ required inhibiting the ACE activity by $50 \%$.

\subsection{Radical scavenging activity measurement using ABTS assay}

Radical scavenging activity of the peptide samples were measured using spectrophotometry as described by Re et al. (1999). ABTS with concentration of $7 \mathrm{mM}$ was prepared. This was then oxidized by adding potassium persulfate $(2.45 \mathrm{mM})$ and kept in a dark room for 12-16 h. The solution was diluted with phosphatebuffered saline (PBS, $\mathrm{pH} 7.4$ ) to reach the absorbance equal to $0.70 \pm 0.02$ at wavelength $734 \mathrm{~nm}$. After adding $10 \mu \mathrm{L}$ of peptide samples to $1 \mathrm{~mL}$ of the ABTS radical solution, the absorbance values were monitored continuously at wavelength $734 \mathrm{~nm}$ for $6 \mathrm{~min}$. The decreases in the absorbance values were used for calculating the radical scavenging activity. The latter was expressed as the concentration of inhibitory peptides $\left(\mu \mathrm{g} . \mathrm{mL}^{-1}\right)$ required quenching the absorbance of the radical cation by $50 \%\left(\mathrm{IC}_{50}\right)$. Trolox, BHA and vitamin $\mathrm{C}$ were considered as controls.

\subsection{Statistical analysis}

Results of the present study were expressed as mean values \pm standard deviations. The significance of the differences between the values was determined with $t$ test ( $P$ value $<0.05$ ) using SPSS version 15.0.

\section{Results and discussion}

\subsection{ACE-inhibitory activity}

By addition of PK to whole camel casein, the DH increased significantly till 60 min and then reached a constant value (data not shown). At the end of enzymatic reaction, the $\mathrm{DH}$ value was about $12 \%$.

To investigate the bioactivity of produced peptides from enzymatic hydrolysis of camel milk caseins, the casein hydrolysates was subjected to the UF membranes with the cutoff of 10,5 , and $3 \mathrm{kDa}$, and fractionated into three portions $(3 \mathrm{kDa}$ permeate, $3 \mathrm{kDa}$ retentate, and $5 \mathrm{kDa}$ retentate). The obtained fractions showed high ACE-inhibitory activity $\left(\mathrm{IC}_{50}=91-157 \mu \mathrm{g} \cdot \mathrm{mL}^{-1}\right)$ in comparison with parental unhydrolyzed casein $\left(\mathrm{IC}_{50}>600 \mu \mathrm{g} \cdot \mathrm{mL}^{-1}\right.$ protein) (Table 1$)$. The permeate with MW $3 \mathrm{kDa}$ and the retentate with MW $3 \mathrm{kDa}$ exhibited higher ACEinhibitory activity $\left(\mathrm{IC}_{50}=91\right.$ and $99 \mu \mathrm{g} \cdot \mathrm{mL}^{-1}$, respectively) than the retentate with MW $5 \mathrm{kDa}\left(\mathrm{IC}_{50}=157 \mu \mathrm{g} \cdot \mathrm{mL}^{-1}\right)$. The permeate fraction with $\mathrm{MW} 3 \mathrm{kDa}$ was further subjected to semi-preparative RP-HPLC (Fig. 1). The higher concentration of acetonitrile (ACN) for elution shows the higher hydrophobicity. Thus, it means that F4 was more hydrophobic than F1-F3, but less hydrophobic than F5-F9. Nine fractions were collected, freeze-dried, and stored for biological activity analysis. Six of the collected fractions (i.e., F3-F8), exhibited ACE-inhibitory activity $\left(\mathrm{IC}_{50}=71-186 \mu \mathrm{g} \cdot \mathrm{mL}^{-1}\right)$ (Fig. 2). The concentration of primary protein 
Table 1 ACE-inhibitory and radical scavenging properties of enzymatic hydrolysates from camel milk casein

\begin{tabular}{lll}
\hline Samples & $\begin{array}{l}\text { ACE I inhibitory activity } \\
\mathrm{IC}_{50}\left(\mu \mathrm{g} \cdot \mathrm{mL}^{-1}\right)\end{array}$ & $\begin{array}{l}\text { Radical scavenging activity } \\
\mathrm{IC}_{50}\left(\mu \mathrm{g} \cdot \mathrm{mL}^{-1}\right)\end{array}$ \\
\hline Whole camel casein & $\mathrm{No}^{\mathrm{c}}$ & $35.0 \pm 0.3^{\mathrm{B}}$ \\
$5 \mathrm{kDa}$ retentate & $157 \pm 11^{\mathrm{b}}$ & $14.0 \pm 0.5^{\mathrm{A}}$ \\
$3 \mathrm{kDa}$ retentate & $99 \pm 9^{\mathrm{a}}$ & $13.5 \pm 0.4^{\mathrm{A}}$ \\
$3 \mathrm{kDa}$ permeate & $91 \pm 20^{\mathrm{a}}$ & $12.6 \pm 0.9^{\mathrm{A}}$ \\
\hline
\end{tabular}

The data marked with different small letters have significantly different $\mathrm{IC}_{50}$ values for ACE-inhibitory activity from each other $(P<0.05)$. The data marked with capital letters have significantly different $\mathrm{IC}_{50}$ values for ABTS radical scavenging activity from each other $(P<0.05)$. Values represent average of three independent measurements \pm standard deviation

No $\mathrm{IC}_{50}$ value was not observed up to $600 \mu \mathrm{g} \cdot \mathrm{mL}^{-1}$

that was subjected to hydrolysis was $25 \mathrm{mg} \cdot \mathrm{mL}^{-1}$ and the concentration of these nine fractions were $\mathrm{F} 1=3.6 \mathrm{mg} \cdot \mathrm{mL}^{-1}, \mathrm{~F} 2=2.8 \mathrm{mg} \cdot \mathrm{mL}^{-1}, \mathrm{~F} 3=3.2 \mathrm{mg} \cdot \mathrm{mL}^{-1}$, $\mathrm{F} 4=4.8 \mathrm{mg} . \mathrm{mL}^{-1}, \mathrm{~F} 5=5.7 \mathrm{mg} . \mathrm{mL}^{-1}, \mathrm{~F} 6=2.8 \mathrm{mg} . \mathrm{mL}^{-1}, \mathrm{~F} 7=2.51 \mathrm{mg} . \mathrm{mL}^{-1}$, $\mathrm{F} 8=4.3 \mathrm{mg} \cdot \mathrm{mL}^{-1}$, and $\mathrm{F} 9=1.4 \mathrm{mg} \cdot \mathrm{mL}^{-1}$. At least the final quantity of fraction F4C was equal to $2 \mathrm{mg} \cdot \mathrm{mL}^{-1}$. The results demonstrated that ACE-inhibitory activities of F3, F4, and F7 were the highest $\left(\mathrm{IC}_{50}=79,73\right.$, and $71 \mu \mathrm{g} \cdot \mathrm{mL}^{-1}$, respectively). F4 fraction was selected for further fractionation and subjected to the same RP-HPLC column. The fraction was then split into three portions (F4A, F4B, and F4C) (Fig. 3), and the bioactivity of the latter were measured (Table 2). Among those, $\mathrm{F} 4 \mathrm{C}$ showed the highest ACE-inhibitory activity $\left(\mathrm{IC}_{50}=36 \mu \mathrm{g} \cdot \mathrm{mL}^{-1}\right)$. The purity of this fraction was verified by analytical RP-HPLC (Fig. 3).

The $\mathrm{IC}_{50}$ values of the peptide fractions obtained in the present study were in the range of 36-600 $\mu \mathrm{g} . \mathrm{mL}^{-1}$, compared with $0.03-0.23 \mathrm{mg} \cdot \mathrm{mL}^{-1}, 21-684 \mu \mathrm{g} \cdot \mathrm{mL}^{-1}$, and $0.32-2.65 \mathrm{mg} \cdot \mathrm{mL}^{-1}$ for lysozyme hydrolysate, bovine casein hydrolysate, and peptides obtained from amaranth grain, respectively (Asoodeh et al. 2012; Jiang et al. 2010; Tovar-Pérez et al. 2009).

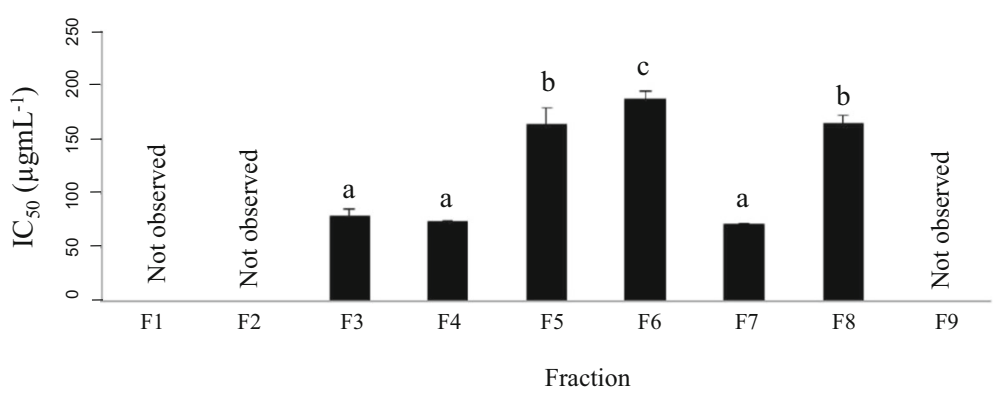

Fig. 2 ACE-inhibitory activity of the collected fractions expressed as $\mathrm{IC}_{50}$ (the concentration of inhibitory peptides needed to inhibit the $\mathrm{ACE}$ activity by $50 \%$ ). $\mathrm{IC}_{50}$ values for $\mathrm{F} 1, \mathrm{~F} 2$, and $\mathrm{F} 9$ fractions were not observed up to $300 \mu \mathrm{g} \cdot \mathrm{mL}^{-1}$. $\mathrm{IC}_{50}$ values are the average of three independent measurements and error bars are standard deviations of the experiments. The data marked with different letters have significantly different $\mathrm{IC}_{50}$ values from each other $(P<0.05)$ 


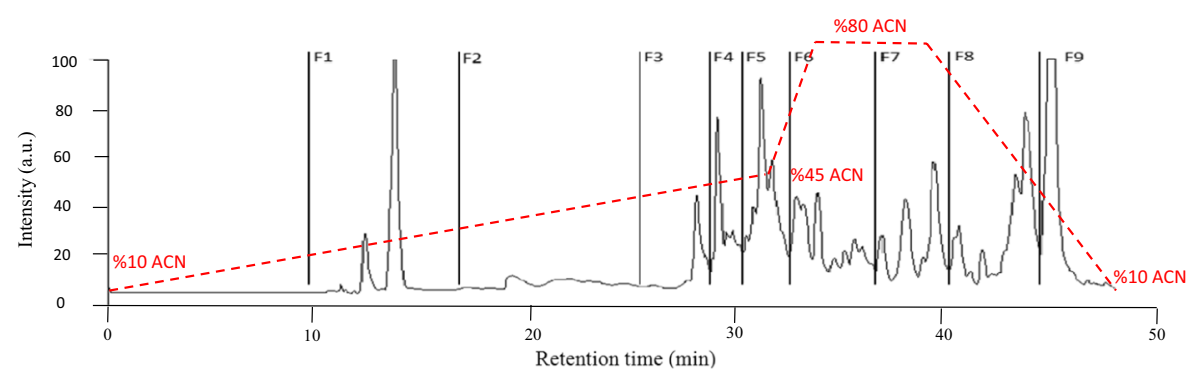

Fig. 3 A representative RP-HPLC chromatogram during fractionation of F4 by use of an ODS C18 column $(L=250 \mathrm{~mm}, \mathrm{ID}=4.6 \mathrm{~mm})$. For elution of the fractions, buffer A $(10 \%$ ACN containing $0.1 \% \mathrm{TFA})$ and buffer B $\left(80 \%\right.$ ACN containing $0.1 \%$ TFA) were used at a flow rate of $1.5 \mathrm{~mL} \cdot \mathrm{min}^{-1}$. The eluted fractions were monitored by UV detector at $215 \mathrm{~nm}$ wavelength. Small insertion represents the chromatogram obtained by injection of $\mathrm{F} 4 \mathrm{C}$ into the column

The high ACE- inhibitory activity of the camel casein hydrolysates corresponds to the high content of proline in camel milk (Moslehishad et al. 2013; Salami et al. 2011). Small peptides with a proline residue at carboxyl terminal have been found to possess strong inhibitory activity against ACE (Korhonen and Pihlanto 2007). It has also been reported that the presence of aliphatic and aromatic amino acid residues in the three carboxyl terminal positions of ACE-inhibitory peptides is important in enhancing their binding to the active site of ACE (Cheung et al. 1980). The results of the present study revealed that $\mathrm{PK}$ is very useful to liberate the bioactive peptides from camel milk casein. PK (EC 3.4.21.64) is a highly proteolytic but low specific serine protease. This microbial enzyme with strong affinity to the hydrophobic amino acid residues hydrolyzes proteins at peptide bounds adjacent to the carboxylic group of aliphatic and aromatic amino acids (Ebeling et al. 1974; Otte et al. 2007). Several anti-hypertensive peptides produced by PK have a proline residue at their carboxyl terminal (Abubakar et al. 1998). Therefore, the high ACE-inhibitory activity of the peptide fractions derived from camel milk casein seems to be due to their small size and the proline located at carboxyl termini.

Table 2 ACE-inhibitory and radical scavenging properties of the fractions obtained from F4

\begin{tabular}{lll}
\hline Samples & $\begin{array}{l}\text { ACE-I inhibitory activity } \\
\mathrm{IC}_{50}\left(\mu \mathrm{g} \cdot \mathrm{mL}^{-1}\right)\end{array}$ & $\begin{array}{l}\text { Radical scavenging activity } \\
\mathrm{IC}_{50}\left(\mu \mathrm{g} \cdot \mathrm{mL}^{-1}\right)\end{array}$ \\
\hline F4A & $317 \pm 13^{\mathrm{b}}$ & $8.5 \pm 0.2^{\mathrm{B}}$ \\
F4B & $\mathrm{No}^{\mathrm{c}}$ & $>100^{\mathrm{C}}$ \\
F4C & $36 \pm 2^{\mathrm{a}}$ & $3.3 \pm 0.1^{\mathrm{A}}$ \\
\hline
\end{tabular}

The data marked with different small letters have significantly different $\mathrm{IC}_{50}$ values for ACE-inhibitory activity from each other $(P<0.05)$. The data marked with capital letters have significantly different $\mathrm{IC}_{50}$ values for ABTS radical scavenging activity from each other $(P<0.05)$. Values represent average of three independent measurements \pm standard deviation

No $\mathrm{IC}_{50}$ value was not observed up to $300 \mu \mathrm{g} \cdot \mathrm{mL}^{-1}$ 


\subsection{ABTS radical scavenging activity}

In this study, radical scavenging potencies of the samples were measured using the ABTS decolorization assay. The UF fractions exhibited high radical scavenging activities $\left(\mathrm{IC}_{50}=12.6-14 \mu \mathrm{g} \cdot \mathrm{mL}^{-1}\right)$ in comparison with the parental unhydrolyzed protein $\left(\mathrm{IC}_{50}=35 \mu \mathrm{g} \cdot \mathrm{mL}^{-1}\right)$ as shown in Table 1 . There were no significant differences between the radical scavenging activities of the obtained fractions. Evaluation of the ABTS radical scavenging potency of the peptide fractions obtained from RP-HPLC showed that fractions with moderate hydrophobicity had the most potent inhibitory activity (Fig. 4). The result of this study is in agreement with study of Tang et al. (2009). The fractions F2-F7 showed higher radical scavenging activity than the parental $3 \mathrm{kDa}$ permeate fraction $\left(\mathrm{IC}_{50}=6.7-12 \mu \mathrm{g} \cdot \mathrm{mL}^{-1}\right)$. On the other hand, $\mathrm{F} 1$, F8, and F9 exhibited lower activities (Fig. 4). Among the collected fractions from RPHPLC, F4 and F5 ( $\mathrm{IC}_{50}=6.8$ and $7 \mu \mathrm{g} \cdot \mathrm{mL}^{-1}$, respectively) exhibited the most potent scavenging activity against the radical. Because of its relatively high ACE-inhibitory and radical scavenging activity, F4 was selected for further fractionation and was subjected to the same column. As mentioned earlier, F4 was then divided into three parts, and the bioactivity of the obtained fractions were measured (Table 2). Among the fractions obtained from further fractionation of $\mathrm{F} 4, \mathrm{~F} 4 \mathrm{C}$ possessed the most potent radical scavenging capacity $\left(\mathrm{IC}_{50}=3.3 \mu \mathrm{g} \cdot \mathrm{mL}^{-1}\right)$. $\mathrm{IC}_{50}$ values of Trolox, BHA, and vitamin $\mathrm{C}$ were also calculated (Fig. 5). These $\mathrm{IC}_{50}$ values, as well as the $\mathrm{IC}_{50}$ value reported previously for vitamin $\mathrm{E}$ ( $\alpha$-tocopherol) $\left(\mathrm{IC}_{50} \approx 15 \mu \mathrm{M}\right.$ or $\left.6.4 \mu \mathrm{g} \cdot \mathrm{mL}^{-1}\right)(\mathrm{Re}$ et al. 1999), were used for comparison with $\mathrm{IC}_{50}$ values of our fractions. The results revealed remarkable ABTS radical scavenging activity of the obtained peptide fractions F3-F8 in this study. As shown in Fig. 5, F4C $\left(\mathrm{IC}_{50}=3.3 \mu \mathrm{g} \cdot \mathrm{mL}^{-1}\right)$ is comparable in ABTS radical scavenging activity with BHA $\left(\mathrm{IC}_{50}=2.1 \mu \mathrm{g} \cdot \mathrm{mL}^{-1}\right)$, vitamin $\mathrm{C}$ $\left(\mathrm{IC}_{50}=2.1 \mu \mathrm{g} \cdot \mathrm{mL}^{-1}\right)$, and Trolox $\left(\mathrm{IC}_{50}=2.9 \mu \mathrm{g} \cdot \mathrm{mL}^{-1}\right)$. Also, in comparison with $\alpha$ tocopherol $\left(\mathrm{IC}_{50} \approx 6.4 \mu \mathrm{g} \cdot \mathrm{mL}^{-1}\right), \mathrm{F} 4 \mathrm{C}$ has a potent $\mathrm{ABTS}$ radical scavenging activity. Better understanding of the biological functions of these peptides requires in vivo tests. Some clinical and experimental studies provided convincing evidence that reactive oxygen species (ROS) play an important role in development of hypertension (Touyz 2004). Therefore, in vivo anti-hypertensive activity of the compounds such as F4C (showing both ACE-inhibitory and antioxidant properties) might be much higher than those expected for in vitro ACE-inhibitory activities.

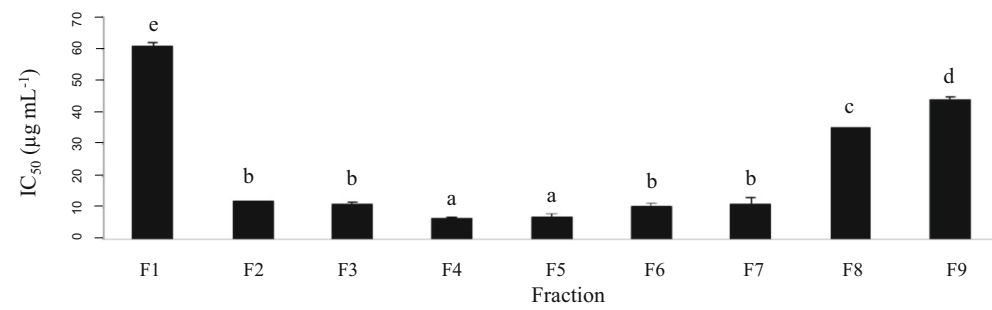

Fig. 4 ABTS radical scavenging activity of the collected fractions expressed as $\mathrm{IC}_{50}$ (the concentration of inhibitory peptides needed to scavenge the ABTS radical by $50 \%$ ). $\mathrm{IC}_{50}$ values are the average of three independent measurements and error bars are standard deviations of the experiments. The data marked with different letters have significantly different $\mathrm{IC}_{50}$ values from each other $(P<0.05)$ 

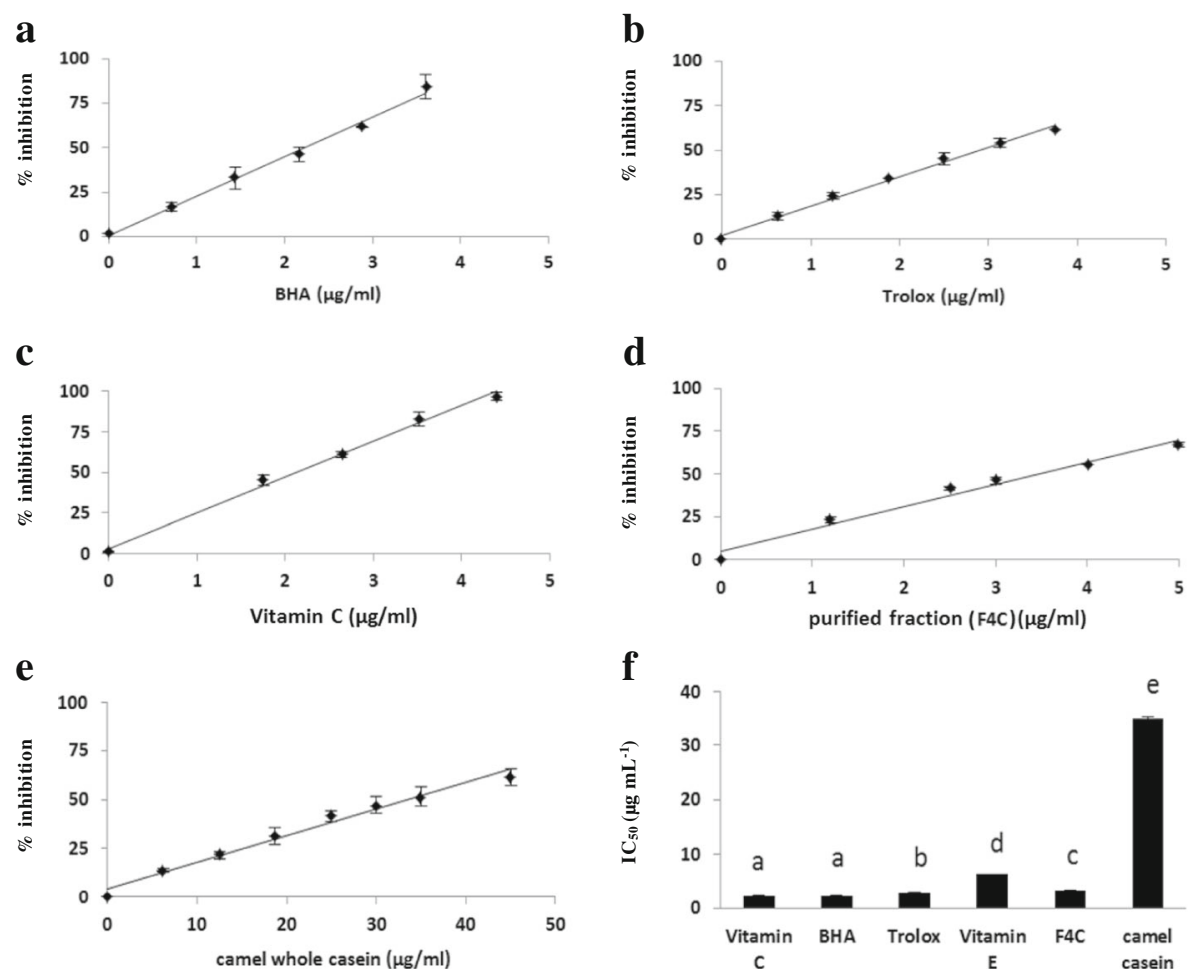

Fig. 5 Comparison of the radical scavenging activities of vitamin C (a), BHA (b), purified fraction F4C (c), Trolox (d), and camel casein (e). f Comparison between radical scavenging activities of vitamin C, BHA, Trolox, vitamin E, camel milk casein, and purified peptide from camel casein (F4C). The data marked with different letters have significantly different $\mathrm{IC}_{50}$ values from each other $(P<0.05)$. $\mathrm{IC}_{50}$ values are the average of three independent measurements and error bars are standard deviations of the experiments

\section{Conclusion}

The results of the present showed that PK is a proper enzyme for liberating peptides with ACE-inhibitory and radical scavenging properties from whole camel casein. Peptides produced by PK are heterogeneous in their biological activities; some of those like F4C show high ACE-inhibitory and antioxidant activity. ACE-inhibitory activity of F4C was almost the same as ACE-inhibitory peptides reported in the literature. In addition to its action on ACE, F4C has also high ABTS radical scavenging activity comparable to that of the most important antioxidants such as vitamin C, BHA, Trolox, and vitamin E. Present work demonstrates that camel casein can be used as a valuable source to produce bioactive peptides with high ACE-inhibitory and antioxidant activities. Comparison to other sources, the $\mathrm{IC}_{50}$ values of the peptide from the whole casein of camel milk was remarkable.

Acknowledgments The support of University of Tehran, International scientific Studies \& Collaboration (CISSC)-Ministry of Science, Research and Technology in Iran, Center of Excellence in Biothermodynamics (CEBiotherm), Iran National Science Foundation (INSF), and Iran National Elites Foundation (INEF) and UNESCO Chair on Interdisciplinary Research in Diabetes, Iran Society of Biophysical Chemistry, is gratefully acknowledged. 


\section{References}

Abubakar A, Saito T, Kitazawa H, Kawai Y, Itoh T (1998) Structural analysis of new antihypertensive peptides derived from cheese whey protein by proteinase K digestion. J Dairy Sci 81:3131-3138

Ali AA, Alyan AA, Bahobail AS (2013) Effect of fermented camel milk and cow milk containing (bifidobacteria) enriched diet in rats fed on cholesterol level. Agric Sci Res J 3:342-346

Asoodeh A, Yazdi MM, Chamani J (2012) Purification and characterisation of angiotensin I converting enzyme inhibitory peptides from lysozyme hydrolysates. Food Chem 131:291-295

Cheung H-S, Wang F-1, Ondetti MA, Sabo EF, Cushman DW (1980) Binding of peptide substrates and inhibitors of angiotensin-converting enzyme. Importance of the $\mathrm{COOH}$-terminal dipeptide sequence. J Biol Chem 255:401-407

Church FC, Swaisgood HE, Porter DH, Catignani GL (1983) Spectrophotometric assay using ophthaldialdehyde for determination of proteolysis in milk and isolated milk proteins. J Dairy Sci 66:1219-1227

Clare D, Swaisgood H (2000) Bioactive milk peptides: a prospectus. J Dairy Sci 83:1187-1195

Ebeling W, Hennrich N, Klockow M, Metz H, Orth HD, Lang H (1974) Proteinase K from Tritirachium album limber. Eur J Biochem 47:91-97

Gorban A, Izzeldin OM (1997) Mineral content of camel milk and colostrum. J Dairy Res 64:471-474

Habib HM, Ibrahim WH, Schneider-Stock R, Hassan HM (2013) Camel milk lactoferrin reduces the proliferation of colorectal cancer cells and exerts antioxidant and DNA damage inhibitory activities. Food Chem 141:148-152

Hooper NM (1991) Angiotensin converting enzyme: implications from molecular biology for its physiological functions. Int J Biochem 23:641-647

Jiang Z, Tian B, Brodkorb A, Huo G (2010) Production, analysis and in vivo evaluation of novel angiotensinI-converting enzyme inhibitory peptides from bovine casein. Food Chem 123:779-786

Jrad Z et al (2014) Effect of digestive enzymes on antimicrobial, radical scavenging and angiotensin I-converting enzyme inhibitory activities of camel colostrum and milk proteins. Dairy Sci Technol 94:205-224

Korhonen H, Pihlanto A (2007) Technological options for the production of health-promoting proteins and peptides derived from milk and colostrum. Curr Pharm Design 13:829-843

Moslehishad M, Ehsani MR, Salami M, Mirdamadi S, Ezzatpanah H, Naslaji AN, Moosavi-Movahedi AA (2013) The comparative assessment of ACE-inhibitory and antioxidant activities of peptide fractions obtained from fermented camel and bovine milk by Lactobacillus rhamnosus PTCC 1637. Int Dairy J 29:82-87

Otte J, Shalaby SM, Zakora M, Pripp AH, El-Shabrawy SA (2007) Angiotensin-converting enzyme inhibitory activity of milk protein hydrolysates: effect of substrate, enzyme and time of hydrolysis. Int Dairy J 17:488-503

Quan S, Tsuda H, Miyamoto T (2008) Angiotensin I-converting enzyme inhibitory peptides in skim milk fermented with Lactobacillus helveticus 130B4 from camel milk in Inner Mongolia, China. J Sci Food Agric 88:2688-2692

Re R, Pellegrini N, Proteggente A, Pannala A, Yang M, Rice-Evans C (1999) Antioxidant activity applying an improved ABTS radical cation decolorization assay. Free Radical Biol Med 26:1231-1237

Salami M et al (2010) Improvement of the antimicrobial and antioxidant activities of camel and bovine whey proteins by limited proteolysis. J Agric Food Chem 58:3297-3302

Salami M, Moosavi-Movahedi AA, Moosavi-Movahedi F, Ehsani MR, Yousefi R, Farhadi M, Niasari-Naslaji A, Saboury AA, Chobert JM, Haertlé T (2011) Biological activity of camel milk casein following enzymatic digestion. J Dairy Res 78:471-478

Shabo Y, Yagil R (2005) Etiology of autism and camel milk as therapy. Int J Disabil Hum Dev 4:67-70

Shalaby SM, Zakora M, Otte J (2006) Performance of two commonly used angiotensin-converting enzyme inhibition assays using FA-PGG and HHL as substrates. J Dairy Res 73:178-186

Skeggs LT, Kahn JR, Lentz K, Shumway NP (1957) The preparation, purification, and amino acid sequence of a polypeptide renin substrate. J Exp Med 106:439-453

Takeda S, Takeshita M, Kikuchi Y, Dashnyam B, Kawahara S, Yoshida H, Watanabe W, Muguruma M, Kurokawa M (2011) Efficacy of oral administration of heat-killed probiotics from Mongolian dairy products against influenza infection in mice: alleviation of influenza infection by its immunomodulatory activity through intestinal immunity. Int Immunopharmacol 11:1976-1983

Tang X, He Z, Dai Y, Xiong YL, Xie M, Chen J (2009) Peptide fractionation and free radical scavenging activity of zein hydrolysate. J Agric Food Chem 58:587-593 
Touyz RM (2004) Reactive oxygen species, vascular oxidative stress, and redox signaling in hypertension what is the clinical significance? Hypertension 44:248-252

Tovar-Pérez E, Guerrero-Legarreta I, Farrés-González A, Soriano-Santos J (2009) Angiotensin I-converting enzyme-inhibitory peptide fractions from albumin 1 and globulin as obtained of amaranth grain. Food Chem 116:437-444

Vermeirssen V, Van Camp J, Verstraete W (2002) Optimisation and validation of an angiotensin-converting enzyme inhibition assay for the screening of bioactive peptides. J Biochem Biophys Methods 51:75-87 